\title{
A Nation Once Again?
}

\section{Faith and Criticism of National Ideas in Romantic and post-Romantic Irish Literature JÓZSEF PAP}

Abstract: This paper will focus on the cultural foundation of modern Irish nationalism in the wake of the Irish Romantic and post-Romantic periods. Through the analysis of representative literary works, the complex system of belief and disbelief in an independent Ireland will be shown. Several generations of Irish writers shared their opinion with the public on the subject of national ideals from the late 1830s onwards, when the Young Ireland Movement Started to grow in influence, and inspired following generations of Irish nationalists. Some of the junior members of the movement went on to found other associations, but the radical changes of borders did not happen until the $20^{\text {th }}$ century. Faith or disbelief in a culturally and politically independent Ireland was expressed not only prior to 1922 (when independence was finally achieved), but it is still an ongoing debate in contemporary academic and literary circles. Before the Good Friday Agreement was signed in 1998 , or even before the Celtic cultural revival Started at the beginning of the $19^{\text {th }}$ century, there had already been a vivid industry working on the definition of Irishness. However, a generation after 1840s the militant tones of national pride were accompanied by milder and more considerate voices as the post-Romanic era came. By examining the problems, forces and counter-forces of this discussion we may arrive at a fuller understanding of Romantic and post-Romantic Irish literature.

This paper will focus on the cultural foundation of modern Irish nationalism in the wake of the Irish Romantic and post-Romantic periods. The complex system of belief and disbelief in an independent Ireland will be shown through the analysis of representative literary works. Several generations of Irish writers shared their opinion with the public on the subject of national ideals from the late 1830s onwards, when the Young Ireland Movement started to grow in influence and inspired following generations of Irish nationalists. Some of the junior members of the movement 
went on to found other associations, but the radical changes of borders did not happen until the $20^{\text {th }}$ century.

Faith or disbelief in a culturally and politically independent Ireland was expressed not only prior to 1922 (when independence was finally achieved), but it is still an ongoing debate in contemporary academic and literary circles. Before the Good Friday Agreement was signed in 1998, or even before the Celtic cultural revival started at the beginning of the $19^{\text {th }}$ century, there had already been a vivid industry working on the definition of Irishness. However, a generation after the 1840s, the militant tones of national pride were accompanied by milder and more considerate voices as the post-Romanic era came. By examining the problems, forces and counter-forces of this discussion, we may arrive at a fuller understanding of Romantic and post-Romantic Irish literature.

The significance of these issues becomes clear if we consider a recent example. A typo found in the published "Brexit letter" has caused some controversy, since the letter referred to Ireland as the "Republic of Ireland," although the official name of the country has been "Ireland" for quite some time now (May). And while this may only be a small mistake, it is one of many instances indicating that the UK government has overlooked the Irish/Northern Irish dimension during Brexit negotiations, as Minister for Foreign Affairs \& Trade, Charlie Flanagan and other MPs pointed out (Flanagan; Fenton).

Namely, that a fine demonstration of century-long struggles is being replayed here. The variations of the upcoming political shifts and the management of borders reassure us about the sensitivity of the topic on which this research elaborates. Such turbulent political forces shaped the literary outlook of the 1840s in Ireland. For a short description, at least three important events should be taken into consideration: Daniel O'Connell's Repeal Association, the tragic impact of the Great Irish Famine, and even before that, the failed Wolf Tone Rising of 1798, the memory of which had an enormous influence over Irish history. There are many reasons why this rebellion, just like many others before it, had failed. One may be that it was not a unified campaign on the rebels' side; they lacked discipline, weapons, leadership and followed a disruptive strategy. Meanwhile, the government had been very successful in sealing off the counties which did not act in unison. Since the Wolf Tone Rising was deeply influenced by the French revolution and was dependent on French military support (reinforcement almost landed at Bantry Bay), Great Britain's 


\section{JÓZSEF PAP}

answer was heavy retaliation. In 1798, the country erupted into a violent rebellion and the aftermath showed the British that having an Irish parliament was a liability, for it did not satisfy Catholics and failed to keep Protestant loyalists secure. As a result, immediately upon the outbreak of the 1798 rebellion, they decided to abolish the Irish parliament (Foster 259-86). Although from 1782 onwards, the conditions for Catholics slowly started to improve and until the revolution there was clear evidence how an Irish parliament may be efficient, ${ }^{1}$ the example of 1798 showed that it was unable to protect itself. From the perspective of Great Britain, a union of the kingdoms was desirable because of the uncertainty that followed the Irish Rebellion and the French Revolution of 1789; if Ireland adopted Catholic emancipation, a Roman Catholic parliament could break away from Britain and ally with the French, while the same measure within a United Kingdom would exclude that possibility. Consequently, by the Act of Union the two kingdoms were united under British control and a sovereign Irish Parliament ceased to exist. Opposing the desired complete separation and independence, the Union was seen as an utmost insult to national pride and self-confidence; it was a national humiliation, a setback that eroded centuries of Irish freedom.

The time for grand-scale armed conflicts was temporarily over and following the Act of Union. a talented nationalist, Daniel O'Connell, rose to new levels of popularity and political success. His main strategy was one of political reform, working within the parliamentary structures of the British state in Ireland. He campaigned for Catholic emancipation - including the right for Catholics to sit in the Westminster Parliament - and repeal of the Act of Union. With the achieved state of Catholic emancipation, conditions for the majority of the population steadily improved, but parliamentarian ways were slowly losing momentum and many fractions left O'Connell's circle. This was due to two major factors. Firstly, the more radical voices who worked in unison with O'Connell criticized him for being an opportunist politician, especially when it came to his relation with British Whig, conservative politicians. Parallel to this in 1843, The Nation newspaper published a poem by John Kells Ingram, the work for which he is best remembered, a political ballad called "The Memory of the Dead" written in honour of the Irish Rebellion of 1798.

1 The Repeal Act of 1782 was an Act of the Parliament of Great Britain, which repealed the Declaratory Act of 1719. The 1719 Act had declared the Parliament of Ireland dependent on the Parliament and Privy Council of Great Britain. The Repeal Act was the first part of the Constitution of 1782, which granted legislative independence to the Kingdom of Ireland. 


\section{A NATION ONGE AGAIN?}

The poet gave voice not only to his own, but to many of the young Irish intellectuals who were stirred by the lack of regard shown for the Irish rebels of ' 98 by the contemporary nationalist movement, led by Daniel O'Connell (Barret). Informally, the poem is better known under the opening line: "Who fears to speak of Ninety-Eight?"

Who fears to speak of Ninety-Eight?

Who blushes at the name?

When cowards mock the patriot's fate

Who hangs his head for shame?

He's all a knave, or half a slave,

Who slights his country thus;

But a true man, like you, man,

Will fill your glass with us. (Regan, "The Memory of the Dead" 162)

O'Connell's dedication to peaceful methods of political agitation of course also meant the exclusion of more radical tones from public life. But for the radicals he was seen as one of those men who fear to speak of '98, which also shows how disputed the memory of the 1798 rebellion was. The poem was published when Daniel O'Connell was at the height of his repeal movement, trying to restore the Irish parliament and it was seen as an expression of support for the memory of 1798 as well as a gesture directed against O’Connell. Secondly, O’Connell had to face a series of scandals challenging his credibility as an MP. There were rumours of secret love affairs and adultery, some of which are now impossible to fully prove or confute. Almost a hundred years later, in a famous speech in the Senate in 1925, W. B. Yeats stated how it was said in O'Connell's time that you could not throw a stick over a workhouse without hitting one of his own children. But Yeats went on to say he believed in the solubility of marriage ("Parliamentary Debates"). Needless to say, these scandals undermined O'Connell's political reputation.

Despite these setbacks, the parliamentarian methods achieved astonishing success, but for the more radical voices this was just not enough, and a new revolution was being prepared. Before this could take place, however, another tragic episode in modern Irish history was about to begin, one that has an impact on the fabric of society up until this day. The population of Ireland in 1845 was 8 million. Within 5 years that number dropped to 6 million. One million Irish people died during the 


\section{JÓZSEF PAP}

five years of the Great Famine and another one million were forced to emigrate. This incredible destruction affected the Irish economy, politics and society. Irish culture changed completely after the famine. For those who emigrated, it also created a legacy of bitterness. They had been forced out of their country; they had been forced to flee, to leave. More disturbing was the message that they had been left to starve while food was being exported from the country. The immediate response to the famine was to settle the issue of responsibility: who was to blame for the tragedy? John Mitchell, the Young Ireland leader, raised the issue of the "Potato Disease" in Ireland as early as 1844 in The Nation. He also described how hunger can be a powerful agent in certain revolutions. The lack of support in some quarters of Britain created anger and resentment. Alexander Martin Sullivan, an Irish nationalist politician and journalist, speculated in his book The Story of the Irish that there was an article in the London Times newspaper from the time of the famine, which stated that the arrival of the potato blight in Ireland was to be considered a "blessing" (qtd. in Thornton). It went on to say that many British looked "forward to the day when an Irish man in Connemara would become as rare as a red Indian in Manhattan" (qtd. in Thornton). No wonder that Mitchel later assumed that "God Almighty sent the potato blight but it was the British who created the famine" (Mitchell 218). The question of who was to blame for the famine is certainly to be explored. Some experts even go as far as to call it a planned genocide, but there are several problems with this claim at best. ${ }^{2}$ Controversial as it was, the contemporaries' overall conclusions provided them with a moral groundwork for any armed conflict for the decades ahead: if the Irish people's suffering is of little or no concern to the governing British forces then the nation's best interest is to separate from the kingdom.

Building on the argument that the country is neglected, the Young Ireland movement organised a rebellion in 1848. The British at that time felt that they were aiding the starving Irish and they considered the rebellion as the worst kind of ingratitude. Interestingly enough, it was not only the famine that inspired the Young Ireland

2 There is a website called www.irishholocaust.org. On its home page the quotation reads: "no Jewish person would ever refer to the "Jewish Oxygen Famine of 1939-1945," so no Irish person ought to ever refer to the Irish Holocaust as a famine." The editors argue in detail that the Irish famine was not a famine, it was genocide, but I think there are problems with using those claims. It is offensive to those who perished in real genocide during the Second World War in a deliberate attempt by the Nazis to exterminate them. There is evidence to prove that British officials did not intend this. The great Irish famine, catastrophic as it was, was no genocide. 


\section{A NATION ONGE AGAIN?}

Rebellion; there was a wave of revolutions that were erupting around Europe at that time. It was seen as the springtime of the peoples and if we look at the history of present-day countries of France, Germany, Czech Republic, Austria or Hungary, there was a strong sentiment that the subjects of crown could assert their own rights and independence; moreover they could abolish the rule of aristocrats forever.

The Irish rebellion (which was also called the Famine Rebellion) was a complete disaster that caused the exile of prominent Irish politicians from the country. Yet, it had a major difference from any other previous armed conflict, mainly because it was preceded by years of intellectual campaigning. The Young Ireland movement and its leader, Thomas Davis, worked on introducing a new kind of Irish nationalism, one that believed that it needed its songs, its stories; it needed its literature; it needed its own identity. Thomas Davis famously proclaimed that Ireland needed to have its own language: "A people without a language of its own is only half a nation. A nation should guard its language more than its territories, 'tis a surer barrier and a more important frontier than mountain or river" (Kearns 409). In contrast, Davis himself did not have a word of Irish and yet he was able to create the symbolism around a new Irish nationalism. His strategy of the national language linked to liberty and a much advertised new art that would support the national identity were desperately needed, although due to the unfortunate early death of Thomas Davis in 1845, the escalation of the potato blight and the English retaliation following the 1848 rebellion, no further development followed in the language question for some time. Part of the cause of the delay was that the issue of a language-based national identity was in conflict with the old-fashioned nationalism of Daniel O'Connell.

In 1801, Ireland became part of the United Kingdom and lost its sovereignty as a country. However, the inspiration from the American War of Independence and the republicanism of the French Revolution had an influence on the way upcoming intellectuals defined national identity.

Among the ranks of the Repeal Association began a tendency associated with The Nation newspaper and The Young Ireland or Éire Óg, a political, cultural and social movement that intended to promote the idea of a national identity in all social classes. The authors included programmatic literary voices, programmatic in the

sense of setting a trend to be followed by a generation of poets. The Nation aimed to promote national and rational recreation. In its first issue a series of arguments 


\section{JÓZSEF PAP}

was started for the "literary and scientific institutions" in Ireland. In this way, the Irish could become "the most cultivated," as they were already "the most virtuous" people in the world (Kearns 408). As a first step, they were to be given national ballads. It is hard to exaggerate the benefits that these nationalists expected from songs. Popular ballads could link classes in a common Irish humanity and teach all a common national history. The writers of The Nation published a series of books on the national cause, the most successful of which was The Spirit of the Nation, a collection of some of the poems and songs published in the paper. This is, again, a slightly different emphasis from that of the Repeal Association, which instead animated its followers through allegiance to the person of Daniel O'Connell.

Davis gave a voice to the $19^{\text {th }}$-century foundational culture of modern Irish nationalism. He and a halo of poets sought for imminent political change in the country's history to create a common and more inclusive base for the future. Looking at the poems of young Thomas Davis, we can see that he actually developed his ideas while he was a student at Trinity College. He borrowed his persuasive tone from his oratory skills honed as a member of the Debating Society and the college's Historical Society. In The Nation newspaper, he also published some of his poems with a more militant, mobilising tone:

'And if, when all a vigil keep

The West's asleep! the West's asleep!

Alas! and well may Erin weep

That Connacht lies in slumber deep.

But, hark! a voice like thunder spake,

The West's awake! the West's awake!

Sing, Oh! hurrah! let England quake,

We'll watch till death for Erin's sake' (Regan, "The West's Asleep" 160)

It is well-established to say that these mobilising tones were fit for their cause, mainly because of the promising functionality rather than aesthetic values. For example, the tone and register are set when 'Ireland' is personified and referred to in Gaelic as 'Erin' and the rise of the country is in a counter position against England. However, these patriotic poems were the first of their kind and had a major influence on the following generations, as will be elaborated later. 


\section{A NATION ONGE AGAIN?}

Another poem by Thomas Davis, A Nation Once Again. Davis wrote many patriotic ballads, among which this may be the most accurate rendition of his and his colleagues' beliefs.

When boyhood's fire was in my blood

I read of ancient freemen,

For Greece and Rome who bravely stood,

Three hundred men and three men;

And then I prayed I yet might see

Our fetters rent in twain,

And Ireland, long a province, be

A Nation once again! (Regan, "A Nation Once Again" 159)

Published in 1844, it quickly became a rallying call for the growing Irish nationalist movement. Besides its obvious popularity, it carried some serious generalisations even by contemporary standards. Ireland (here without the Gael transcription) is now compared to archaic Greek and Roman territories. Furthermore, what really causes some confusion is that in the refrain of the poem it is questionable what kind of nation the speaker would like to return to. Just to mention a few ideas, is it a reference to the parliamentarian era prior to the Wolf Tone Rising, or does it go back even further to a pre-colonised state in the island, without a British influence, a Gaelic Ireland? In this sense, especially in this collection of works, I feel obliged to call attention to Coleridge's idea of the suspension of disbelief: that willing suspension of disbelief for the moment, which constitutes poetic faith (Biographia Literaria, Chapter 4). The poetic faith in this case is necessary to conjure up belief in a free Ireland, an act that requires strong belief. The Young Irelanders longed to see the liberties achieved on the Continent achieved in Ireland. With that in mind, they simply disregarded any factors that went against this chosen rhetoric. Namely, that with a Protestant minority, with class and religious diversity on the island, there is no archaic, let alone authentic, Irish nation to return to. Additionally, Thomas Davis was not even afraid of the aestheticization of violence in his works which implies that taking up arms against the oppressors is responsible for a heroic outlook.

Aside from the chief organiser, Thomas Davis, there were other voices in the Nation circle as well. Firstly, Samuel Fergusson may be mentioned who revitalised 


\section{JÓZSEF PAP}

the keening poetic tradition, a lament tradition to be exact, famously for the funeral of Thomas Davis. James Mangan was another prominent example from a literary point of view. Although his early poetry was often apolitical, after the Great Famine he began writing patriotic poems, including influential works such as "Dark Rosaleen," a translation of Antoine Ó Raifteirí’s Róisín Dubh, a political song disguised as a love song. Raifteirí was a travelling bard who lived between 1779 and 1835. He made a life for himself writing songs and poetry, often performing them in the mansions of the Anglo-Irish gentry. He wrote in Irish and the peculiar irony of the case was that his patriotic song was to be translated to the supposed oppressors' language for an Irish audience to enjoy. ${ }^{3}$

O my dark Rosaleen,

Do not sigh, do not weep!

The priests are on the ocean green

They march along the deep.

There's wine from the royal Pope

Upon the ocean green;

And Spanish ale shall give you hope,

My Dark Rosaleen!

My own Rosaleen!(Regan, "Dark Rosaleen” 146)

I may call attention to the religious references in the image of "wine from the royal Pope" and the Catholic solidarity in the form of "Spanish ale." Closely related, but prior to this poem, the adaptation of a popular ballad motif Kathaleen $\mathrm{Ny}$-Houlahan was published. Here, the female character, which also stands for Ireland, is in urgent need of physical and spiritual rejuvenation:

Long they pine in weary woe, the nobles of our land,

Long they wander to and fro, proscribed, alas! and banned;

Feastless, houseless, altarless, they bear the exile's brand,

But their hope is in the coming-to of Kathaleen-Ny-Houlahan!

3 The Nation newspaper was published almost exclusively in English and Mangan probably used Ferguson's literal translation to write this poem. 


\section{A NATION ONCE AGAIN?}

He, who over sands and waves led Israel along-

He, who fed, with heavenly bread, that chosen tribe and throng-

He, who stood by Moses, when his foes were fierce and strong-

May He show forth His might in saving KathaleenNy-Houlahan. (Regan,

"Kathaleen Ny-Houlahan" 145)

To give an idea about the long-lasting after effect and the popularity of this motif, Richard Kearney suggested that the Kathleen Ni Houlihan myth represents the view that the blood sacrifice of heroes is needed to free and redeem Ireland (218). At the same time, these heroic sacrificial martyrs are rewarded by being "remembered for ever." This nationalist sacrificial mythology can be tied to pagan concepts of "seasonal rejuvenation" as well as the sacrificial aspects of Christianity and the tradition of martyrdom. Kearney went on to add that in the 1981 Irish hunger strike of Irish Republican Army prisoners, the same ideology is traceable.

Unlike in the works of Thomas Davis, a different cultural approach to the nationalist question appeared with Mangan. Old Irish poetic structures and forms were revisited, making him, I would suggest, a forerunner and promoter of Irish cultural revival and not necessarily a political revivalist. This shift in tone carries the main significance here, because by the end of the century, the "real" revivalist followed this cultural tradition of their predecessors, but not their demanding political programme.

Later, at the end of the century, W. B. Yeats insisted on the order of first becoming culturally independent in Ireland and then politically independent, but the splitting of these two endeavours was definitely a perquisite: cultural nationalism, but from an Anglo-Irish background, a separation of cultural and political nationalisms. With all his predecessors already exploiting several popular myths and ballads, motifs and traditions, Yeats and his contemporaries still had a lot to do from a cultural nationalist's point of view. The reason I call this era the post-Romantic period, in an Irish context, is self-explanatory. After the failed Young Ireland rebellion and the coming British retribution, in addition to the Great Famine decimating the population, the following generations inherited an incomplete Irish national identity. They needed to finish (or restart) the process of becoming a culturally independent nation, but the aftermath of these tragedies promised little success. More specifically, the native language suffered irreversible damage. Yet against these unfavourable 


\section{JÓZSEF PAP}

odds, Yeats succeeded in opening new horizons to the Cathleen ni Houlihan myth, the aisling and lament traditions and other resurrected Irish topoi. He also explicitly referred to the political legacy left behind by the Young Ireland movement. In his poem, Parnell, written in 1891, he comments on the national question: "Parnell came down the road, he said to a cheering man: / 'Ireland shall get her freedom and you still break stone"” (Yeats 267). Even if Ireland's freedom and independence are achieved, nothing will change for the poor. The cheering man Yeats talks about is a poor man excited about Ireland becoming free, since that should mean he, as a poor man, will be able to make a better living for himself. However, Parnell says even if Ireland becomes independent, you will break stone just as you always have, referring to the lack of immediate benefit that certain classes in society will see from Irish freedom. Another famous example, September 1913, was written midway through his life as a highly reflective poem:

What need you, being come to sense,

But fumble in a greasy till

And add the halfpence to the pence

And prayer to shivering prayer, until

You have dried the marrow from the bone;

For men were born to pray and save:

Romantic Ireland's dead and gone,

It's with O'Leary in the grave. (Regan, "September 1913" 346)

Yeats' repetition of the phrase "Romantic Ireland" connects the politically motivated ideals of the Romantics to an Irish national landscape. Attaching a second repetition of "It's with O'Leary in the grave" (a leading Fenian figure and a contemporary to the Young Irelanders), he indicates the speaker's belief that John O'Leary embodied a nationalism in his political actions that now rests solely within a poetic framework. Indeed, John O'Leary had a great influence on Yeats' early political view of combining Romanticism with the quest for political sovereignty into an original synthesis. In other words, O'Leary's influence on Yeats enables the poet to inherit the literary legacy of the Romantics while carrying on the nationalistic vision of O'Leary. And even after this, Yeats remained oppositional to political violence. He preferred a parliamentarian framework for changes. 


\section{A NATION ONGE AGAIN?}

In conclusion, Yeats did not have the last word on the national question, but it is obvious that his rejection of a simplified national definition and legacy cast a long shadow not just on the poetry, but also on the political view for the coming times. In 2004, George Boyce concluded in the preface to his book on Irish nationalism:

if the present truce [the Belfast Agreement, signed in 1998] is to turn out not merely an interlude between wars all need to recognise that Ireland has not one but many histories; and a long study of nationalism in Ireland suggests that the outcome of the political process is not only unpredictable, but also unlikely to satisfy all those who wish to see Ireland as "a nation once again." (Boyce, "Preface to the third Edition")

There is a long history of interrelation between poetry and politics in Ireland and in some of these examples the difference is hard to tell. The purpose of poetry for the Young Ireland movement was a mean of rhetoric which served the national cause well. It was only later in the $19^{\text {th }}$ century when authors looked for a way to distinguish their work from the general written corpus of the national Zeitgeist. This detachment slowly laid the foundation for a standard, which Irish poets have been constructing and deconstructing up until the present day with each writer highlighting a unique aspect.

\section{Works Gited}

Barret, Sean D. “John Kells Ingram.” In Trinity Economic Paper Series Paper No. 99/9, TCD, II Sept. 2004. www.tcd.ie.

Boyce, D. George. Nationalism in Ireland. London: Routledge, 2004.

Coleridge, Samuel Taylor. BiographiaLiteraria. Full text of Biographia Literaria.

Chapters I-4. I4-22. www.archive.org. Originally published in I8I7.

The Nation. Irish Newspaper Archives. www.irishnewsarchive.com.

Fenton, Siobhan. "Northern Ireland has our only EU border. Theresa May ignores

it at her peril." In The Guardian. Guardian News and Media, 29 Mar. 2017. www.theguardian.com.

Flanagan, Charlie. "Specific reference to Ireland in British PM's letter to President

Tusk" Twitter. N. p.: Twitter, 29 Mar. 20I7. www.twitter.com. 


\section{JÓZSEF PAP}

Foster, Robert F. "Modern Ireland I600-I972." Modern Ireland I60o-1972. London: Penguin Books, 20II. 259-86.

Kearney, Richard. Transitions: Narratives in Modern Irish Culture. Manchester: Manchester University Press, I988. 2 I8.

MacManus, Seumas. "The Story of the Irish Race." The Story of the Irish Race. Cosimo Inc., 2005. 610. Qtd. in Allusions in Ulysses by Weldon Thornton.

May, Theresa. "Prime Minister's Letter to European Council President Donald Tusk." UK, 29 Mar. 2017. www.gov.uk.

Mitchel, John. The last conquest of Ireland (Perhaps). Ed. Maume, Patrick. Dublin: University College Dublin press, 2005. 218.

Mitchell, John. "Hunger." The Nation, I Nov. 1844.

"Parliamentary Debates. Debate on Divorce Legislation Resumed." Oireachtasdebates, II June i925. www.oireachtas.ie/en/debates/find/.

Regan, Stephen. Irish Writing: An Anthology of Irish Literature in English I789-1939. Oxford University Press, 2008.

Yeats, W. B. The Collected Poems of W.B. Yeats. Ed. Watts, Cedric. Ware, Hertfordshire: Wordsworth Editions, 2008.

\section{Contributor Details}

József Pap finished his MA studies in 2016 and is currently writing his dissertation on contemporary Irish and Northern Irish poetry at the Doctoral School of Literary Studies at Eötvös Loránd University, Budapest. He is an active translator of W. B. Yeats and Michael Longley. 